\title{
Funerary Symbols in Oe Kenzaburo's the Silent Cry (1967) and Masuji Ibuse's Black Rain (1970)
}

\author{
James Nderitu ${ }^{1 *}$, Dr. J. K. S. Makokha ${ }^{2}$, Prof. John Mugubi ${ }^{3}$ \\ ${ }^{1}$ Kenyatta University \\ ${ }^{2}$ Kenyatta University, Department of Literature, Linguistics and Foreign Languages \\ ${ }^{3}$ Dean, School of Creative and Performing Arts, Film and Media Studies
}

*Corresponding Author: James Nderitu, Kenyatta University

\begin{abstract}
This research paper is based on the study of the primary texts; Masuji Ibuse's Black Rain (1970) and Oe Kenzaburo's The Silent Cry (1967). It seeks to identify and examine the significance of funerary symbols in the two selected novels. The paper also looks at the influence that funerary symbols have on plot, characterization and themes in the texts. A writer uses one form of communication over another in his or her work for a reason. An interrogation of available scholarship on Japanese writers indicates that the area covered by this research has not been exhausted. This study and its findings address this research paucity and invoke further research. The research design is descriptive. Since this is a library based research, the primary texts were read alongside other critical works deemed relevant for the findings of the research. The results from the primary data were then analyzed before the final findings. This study was conducted within the guidelines of two theoretical frameworks: Semiotics Literary theory and Psychoanalytic literary theory. Semiotics literary approach is instrumental when it comes to analyzing the communication modes embraced by the two authors. Psychoanalysis is useful in analyzing the funerary symbols employed by the selected authors.
\end{abstract}

Keywords: Aesthetics, Funerary Symbols, Ibuse, Japanese fiction, Kenzaburo

\section{INTRODUCTION}

In this paper, we start by identifying the funerary symbols employed in the two texts under study in this work, comparatively. In the second part of the paper, the funerary symbols employed in individual texts, but not reflected in the other text, are explained. For the ease of accomplishing this, several ways were employed. The selected texts by Oe Kenzaburo and Masuji Ibuse greatly helped in putting their names in the world map as some of the most renowned literary writers.

\subsection{The Silent Cry}

Oe (1967), The Silent Cry is an award winning text and remains his most popular text. The author himself admits that he has a special preference for the text which he considers to be the best of his works. The text is based on the condition of his first born son who was born with a disability. The situation of the son disturbed him so much that he was inspired to write the text by the very son's predicament. The work, however, is purely fictional.

The narrator in the text talks about his only child who is badly handicapped and in an institution. The condition of the child seriously deteriorates and so does the marriage relationship between the narrator and his wife. The two never get another child together, and their handicapped child whom they are both ashamed of remains in the institution to the end of the text. The child, a friend who commits suicide and the only brother the narrator has are the main things that occupy the narrator's mind. His wife and the brother get into sexual affair from which she conceives. The narrator contemplates committing suicide several times. The Silent Cry helped the author, Kenzaburo Oe, to win the world's most coveted literary prize, Nobel Prize, in the year 1994. The text remains a major text in the world.

\subsection{Black Rain}

Masuji Ibuse is best known for his text, Black Rain that centres on the effects of the Second World War. The text has won him various literary 
prizes and has been widely read the world over. The author, in the text, tries to recollect the memories of the Second World War. Through the narrator, Shizuma, we are shown these effects of war on the common man who may not be concerned with the war. The narrator's own family is affected as the narrator himself has radiation sickness although- his case is mild, Yasuko- his niece, is rained on and gets black spots from which she later develops full blown radiation sickness and suffers a lot from it. The war, as written by this literary scholar, affects the common man more than it does the leaders and the people who declare and run it within the government. Through Masuji Ibuse the reader is provided with an alternative view of the devastating Second World War. This is detailed and more critical. Through Ibuse (1970),Black Rain, Ibuse has won for himself Japan's Naoki literary prize, Noma literary prize and Order of Cultural Merit prize which is the greatest literary prize one can win in Japan.

This paper identifies the funerary symbols used in each of these texts in the context of the Japanese community and specific contexts in each of the texts. The funerary symbols identified are expounded on.

\section{ChaRACTERS AS FUNERARY SYMBOLS}

The two authors have employed some of their characters uniquely in order to advance their messages in their texts. Masuji Ibuse employs Yasuko, a young girl of marriageable age who moves to stay with her uncle, as one of the major characters and a funerary symbol. Oe (1967) on his part employs Takashi who is a younger brother to the narrator of the story and also a major character as a funerary symbol. Like Yasuko, Takashi also moves from oversees country to join the narrator's family in Japan. The two characters move in with the narrators in their respective texts and end up appearing as some of the main human figures employed by the authors as funerary symbols.

Yasuko is the niece to the narrator in the narrative, Shigematsu Shizuma, and one of the main characters in Ibuse's Black Rain. She comes to stay with the narrator's family on the request of the narrator himself. She is however said to have got the radiation disease that was the resultant of the atomic bomb dropped on Hiroshima and Nagasaki. Because of this it becomes hard to find a marriage partner for her. When she starts showing the symptoms for the disease, and later on it develops into a full blown sickness, she causes her hosts a lot of discomfort. Out of fear and embarrassment she had opted to keep her suffering secret. Because of this she becomes a source of suffering, both physical and psychological to those close to her, Shigematsu and his wife Shigeko: For several years past, Shigematsu Shizuma, of the village of Kobatake, had been aware of his niece Yasuko as a weight on his mind (p. 9).

In Oe's The Silent Cry, Takashi who is the only surviving close relative to Mitsusaburo the narrator, also finds himself in a sickness that he would have wished to keep to himself. He contracts a sexually transmitted disease, from his promiscuity, and suffers as he tries to seek help privately and even to keep it away from the doctors how he had contracted it. He is, however, able to get treated for that and to move on with his life. When he moves in with his brother in the valley, he becomes a pain in the neck to his brother, and other people close to him, in most of the things he does.

Both Takashi and Yasuko cause their families a lot of discomfort. Upon coming over to Japan and getting a descent welcome, Takashi sets out to outshine his senior brother. He saves a life, a young boy, who is stuck in a broken bridge, not out of good will but in an open malicious case of competition with the unsuspecting narrator and brother. He also solely sells off the family land, even though he is the younger brother, without proper consultations with the elder brother and what's more- he cheats his brother out of his fair share. Mitsusaburo, who is also the narrator says this about Takashi: "... and Takashi had in fact already sold all the Nekodoro's land and buildings, including Jin's home. If anything qualified Takashi for the role of evildoer, it was the flaw in his sensibility that allowed him so easily to betray the pitiful plans of a middle-aged woman trapped by her abnormal bulk in this godforsaken valley" (p. 164).

In an open case of distaste, he agitates Mitsusaburo when he pokes at Mitsusaburo's suitcase with the toe of the gym shoes he had been wearing for football practice. As she comes to terms with her failing health, Yasuko decides solely to write to her suitor and discloses her condition to him. This greatly disappoints her uncle and aunt as she does this without consulting them in any way. Her sole decision does not only expose her and keep the suitor off, it also dashes her family's hope of having her 
establish her own family. The unprecedented turn of events and the pain her family and she herself are in, is best described in the words of May (2003): Young and lovely, she is no longer marriageable; she will perhaps never have children, or if she does they too may be trapped by the less tangible wreckage of the atomic detonation above Hiroshima. After all, buildings and streets can be healed long before human souls and anatomies have even begun to recover.

Both of the two major characters in the two texts find themselves in suffering that cannot be contained and has to be confessed at one time. Yasuko's pain is mainly in the physical while Takashi's pain is mainly psychological. This means that the suffering of the characters end up being a concern of the others close to them. When Yasuko realizes that she cannot contain her suffering anymore she moves to her uncle and confronts him with the devastating news on her deteriorating health.

This Shizuma finds very disturbing. He is in the living room when she confronts him with the sad news of her failing health; which includes constant ringing sound in her ears. The effect this has on him is seen from what happens in him, in a moment he thinks he sees the room disappearing and in its place he sees a great mushroom-like crowd in the sky (another funerary symbol). In The Silent Cry, Takashi, who has kept some secrets on the illicit sexual affair he had with the sister, realizes that he cannot keep that to himself anymore. With the desire to confess and perhaps get relieved, he goes to his brother Mitsusaburo and makes that confession. He tells him of his close relationship with the sister and people's talk, and how one thing led to another until he ended up having carnal knowledge with her (p. 236). These confessions and revelations end up hurting Shizuma and Mitsusaburo who are the major characters and narrators in the texts. They create a gloomy mood in the end.

Yasuko and Takashi in the respective texts try to finds their own ways of finding cure to their illnesses, something that could have devastating effects if it were to leak to outsiders. Takashi seeks the assistance of a nurse from a medical office in the hotel he was staying in America in order to get medication: "If the trick came to light a young black nurse would get fired and I'd be deported, I imagine." (p. ). In a private talk between Shigeko and Dr Kajita who treats Yasuko, the doctor informs her that Yasuko had attempted to treat herself. Due to this, in the evening Shigeko calls her husband out of the house and they discuss this.

It is clear from their talk that the attempts by the girl to treat herself would not be good news at all. If it were to be known by other people, such would really have a damaging effect on their reputation. This is because it would be concluded that the two had neglected her because she suffered an incurable disease (Oe, 1967, p. 223). Yasuko's attempt to find treatment without involving her uncle and aunt is a reflection of the psychological suffering she undergoes on learning of the symptoms of the radiation disease - this is also the case with Takashi in The Silent Cry. Plans are underway to marry Yasuko off and she knows that all these will not materialize if her condition is known to the public. The main problem for her, already, is arranging a marriage for her when there is a rumour that she may be suffering from radiation sickness (Lichtenstein, 1994, p. ). Because of these fears they resolve to keep that information to themselves. Yasuko's actions and those of Takashi, do not portend well to those who are close to her.

A woman from Ikemoto, whose name is not given, has been used in Ibuse's Black Rain to show the public's attitude towards the victims of the radiation disease. Shigematsu gets to dislike her because she causes him a lot of emotional pain. The woman does not seem to understand what the victims of the radiation disease go through and why they need to have a different lifestyle. In a scathing sarcasm she appears to suggest that Shigematsu and Shokichi, who were fishing at the banks of the lake at Agiyama, were just lazy people for not finding something useful and much more demanding to do. Later on Shokichi, while commenting on the woman says, "I'm so eager to give the woman at Ikemoto's a taste of her own medicine." (Ibuse, p. 31) This is the same case with what Oe writes in his text. While the people are grappling with the radiation disease in Black Rain, the situation in The Silent Cry has to do with the rains and floods.

Yasuko and Takashi bring gloom in their families in their respective texts. Yasuko though does most of this with good intentions and ends up hurting the ones close to her unknowingly. Takashi, however, goes into an offensive against his brother intentionally. His intention is to blackmail his senior brother and to steal the limelight from him and get all the glory through his doings. Mitsusaburo cannot help noting and feeling that his younger brother is out to demean him before his organization of young men, the footballers. In one of the occasions he replies to Takashi's question, on whether he knew 
how to prepare a pheasant, by saying he would try, the youth sigh with disgust. This incident leads Mitsusaburo into believing that the incident had been a set up intended at humiliating him. He is indeed humiliated and his ego hurt: "The young men had been treated to the spectacle of their leader twisting his elder brother round his little finger once again." (Oe, p. 148)

The onslaught by Takashi continues when he openly gets into a sexual relationship with his brother's wife. This he does openly, something that greatly disturbs Mitsusaburo. When he discovers this he says this about the incident: “...but Takashi's arm, which was obviously stretched out to touch my wife's side beneath the blanket, gave the impression that the two were sleeping quite alone" (p.161). The effect on him is immediate. He says, "...I handed the bucket to Jin's son in front of the main house so that I shouldn't have to see the people asleep in there again..." (p. 162)

The period that follows the dropping of the atomic bomb becomes one of pain and lamentations as those people infected with the atomic disease undergo an incomparable pain. It is due to this that the victims of the atomic disease are feared and avoided. The rest of the populace fears Yasuko because they do not know whether she would infect them or have children who would suffer her predicament. These include her fiancé who cuts all the communication with her when he learns that she is suffering from the atomic disease. Takashi is also feared by some of the people who were close to him. He is, however, feared and avoided by people because of his brutal and callous nature. After killing a girl he intended to rape Takashi describes the event in a state that truly shows him to be a dangerous and cold man. He kills her using a stone (Oe, p. 224). Natsumi expresses her fear that a case of murder would not be entirely impossible to Takashi. After giving his account of the alleged killing, Hoshio is filled with fear of mortal death that he expresses his lack of desire for sleep. He tells Takashi, "I don't want to go to sleep, Taka! I feel I might never wake up again.” (p. 232).

Takashi's violent nature also deeply affects Mitsusaburo. Takashi is reported to attack a defenseless young man whom they drop from the group, the feeling of Mitsusaburo as he witnesses this shows what he thought of his brother, "A sense of real physical horror at seeing a close relative in the act of violence thrust down hard and massive into my stomach," (p.177). He eventually loses his sleep after the incident. He also sends a strain of fear in the whole valley when he turns his group of 'footballers' into a militaristic group. In order to implicate everybody in the looting that takes place at the supermarket, Takashi directs his young men to ensure that every family in the valley gets involved, forcefully.

When the carefree Natsumi and Takashi get into an illicit sexual affair behind Mitsusaburo's back, Hoshio; who gets to know of it, feels so bad that he even requests Mitsusaburo whether he can join him in the storehouse. He tells Mitsusaburo about it and he too is disturbed by the turn of events (p. 209). When he later confesses this to his brother, Takashi says this about Hoshio, "After he watched us making love I saw him quietly being sick...." (p. 221).

Once, Takashi leaves the house at night and moves out into the darkness and snow. Mitsusaburo happens to witness this from the storehouse. He is more disturbed by the fact that Takashi has erected and does not do anything to hide it. Mitsusaburo thinks, "Morally, only a dog or some such animal would expose its erect penis so frankly and so pathetically with little purpose." (p.147). When Mitsusaburo goes back to sleep he is disturbed by such thoughts in relation to those of a dog. Takashi is one of the main factors for things going the unpleasant way to Mitsusaburo.

Yasuko and Takashi have been developed by the authors themselves as funerary symbols within the contexts of the novels. Yasuko, for instance, develops the radiation sickness symptoms after Shizuma but suffers the more. Shigematsu, Shigeko and other people close to her suffer silently as her condition worsens. This is from knowing that they cannot do much to help her. This is the same case with Takashi whose mannerisms leads to his death in the end.

Beside the major characters in the texts, the authors of the two selected texts have also employed the images of children as funerary symbols. Mitsusaburo who is the brother to Takashi and the narrator, keeps on being disturbed by the thoughts of his disabled son (Oe: 32) whom he had placed in an institution. He opts to keep his child away in an institution with the approval of his wife for the child's own good and to also avoid further mental torment. He, however, cannot help being revisited by the very child in his dreams (Oe, p. 32)

One of the disturbing things that Shigematsu sees is a child who suckles her mother who is already dead. Not knowing or being in a position to help Shigematsu (Ibuse, p. 107) and the others move on. 
But the memory sticks. The child "...opened the corpse's dress at the top and was playing with the breasts." When they move towards the child she "...clutched tight at both breasts and gazed up at us with apprehensive eyes" (p.107).

Mitsusaburo tells of the agony his wife and himself went through as their baby underwent an operation. He himself, not his wife, is called into the operating theatre to give blood transfusions, "...I - not my wife - was summoned three times to the operating theatre to give blood transfusions..." (Oe, p. 44). This is something that torments the narrator continuously. The disabled child causes a lot of change in the relation between Mitsusaburo and the wife. The wife deserts him for the brother, and at the same time drinks a lot. On his part, Mitsusaburo keeps being haunted by the same. In a bus they are travelling in, Mitsusaburo and his wife (p. 43) see a baby in a likely bad health and this incident immediately arouses the bitter memories about their own son. They get bitter as what they would have wished to forget is aroused: "With bloodshot eyes, red like plums, in which the traces of toxicity still lingered, my wife took note of the child. I too found my eyes drawn irresistibly and with loathing toward him. His head and the color of his skin were such as to bring back our worst memories...." (p. 43)

Jin, another character in Oe's The Silent Cry blames the Koreans who have settled in the valley for most of the misfortunes. She blames them for "...grabbing the valley's land and money" (p.188) and also for causing the death of S. who was a brother to Mitsusaburo. Takashi makes the people to further believe that they are exploited by the Koreans. He spreads this propaganda as he struggles to spread his influence. The effect of Takashi's propaganda is brought clearly out as even children are seen to take side against the Koreans as they openly insult and throw snowballs at the manager of a Korean owned supermarket.

A man who travels with Shigematsu (Ibuse, 1970, p.274) causes a lot of fear and gloom as he spreads false news concerning the ongoing war between Japan and other powers. The man informs all people who care to listen to him that all men would be castrated if the American forces defeat and occupy Japan; he further says that all the people who were visiting Hiroshima after the dropping of the atomic bomb were dying due to the nature of the bomb. Though Shigematsu was to find later on the news to be mere false propaganda, the man killed people's spirit and will to fight at a time they needed to focus on war. Mitsusaburo's wife firmly believes that her husband was to blame for the misfortune of having a deformed child; she blames him for it and denies him his conjugal rights. She, like the man in the trains that Shigematsu uses, advances these false claims. She also believes that Mitsusaburo makes life unbearable not only for her but also for Takashi: "Even when he all but went on his knees and begged you to tell him why you hated him, you wouldn't say, 'I don't hate you'” (Oe, p. 259)

Mitsusaburo is constantly disturbed by the memory of a close friend of his who committed suicide. These memories linger into his mind constantly that he himself contemplates committing suicide as a possible to his own troubles (Oe, p.4). Ibuse (1970) also uses images of dead people as symbols. Shigematsu and his family, in company of other people, while escaping air attacks from foreign forces encounter very many dead bodies, some very devastating, that they seem to lose hope at some time. The effects of the dead over the living are clear. Though Japan is not the leading country in suicide cases in the world, suicide cases are not uncommon (Austin, 2014, para...)

The Korean folk tales a woman with red eyes, like plums is regarded as having eaten human flesh (Oe, p. 26). This folk tale case is brought out through the recollection of Mitsusaburo's wife who has become a habitual alcoholic and who is drinking to escape the reality of her own life.

\section{WAR}

Fear of not knowing what is to happen next is a common thing that keeps recurring in the two texts. This is especially so in Ibuse's Black Rain which lays emphasis on the issue of war. When people see smoke from the city of Hiroshima they get shaken because to them that is an outcome of yet another attack on the people and their property. Smoke and fire have already gained symbolic meanings and these are funerary. One of the characters, Nojima, describes the extra ordinary smoke like one from a volcano. He describes the effect of this smoke on himself when he says that "my knees as I squatted there shook so uncontrollably that I pressed them against a rock, heedless of a small white flower clinging to it" (Ibuse, p.22). His conclusion is that a new bomb weapon must have been dropped by the enemy army. The women who are in Nojima's company deliberately avoid looking towards the city because the sight of the smoke has caused them fear (p. 23). The author has therefore, 
successfully employed smoke in the text as a funerary symbol. When the pheasants die and have to be burned (Oe, p.156) it is the smoke that makes people get to know what had happened. The smell that follows is so awful that it arouses memories of a burned black person in Mitsusaburo's mind .

The war that takes place between the opposing world powers is fought in different forms, fire being one of them (Ibuse, p. 97). Takashi and his group also use fire as a weapon in different instances in Black Rain. The bombs dropped in Hiroshima by enemy forces cause fires every now and then. They cause a lot of confusion, displacements, deaths and physical pain: "Indeed, the fires of Hiroshima were spreading wider and wider, and it was only sensible to get out of their way for a while." (Ibuse, p. 41). In The Silent Cry fire is used to punish or as a tool of correction, Mitsusaburo remembers about a case of a photograph of a black person who had been burned by fire (Oe, p.156). Loosely dangling electric wires in the streets pose a danger of causing fire or of another form: "It occurred to me that they were awfully dangerous" (Ibuse, p. 38). The first form of fire in Black Rain are the flames that are caused by the dropping of a bomb. The fires appear to destroy what is not destroyed directly by the bomb itself. When Shigematsu doesn't see Mrs. Takahashi again and he concludes that "I expect she was caught in the flames." (Ibuse, p. 52).

Another fire is the one that destroys Miyaji's and Shigematsu Shizuma's property. Miyaji who is in pain of loss comments on the fire: "...the tips of the flames are like snakes- they flicker their tongues in at the windows first, then they crawl right inside." (Ibuse, p. 82) He gives the destructive fire animate features to show the almost malicious-like intent as it consumed his wealth and hurt him. Iwatake, Miyoshi and Ito, who are needy, are also forced to flee for safety because of the fire. Iwatake does not only sustain burns but is also forced to leave behind a man in real mortal danger ( Ibuse, p. 248)

Shigematsu describes hill fires, through which they walk with Yasuko and his wife, as very dangerous (Ibuse, p.57). He, in fact, compares a walk through them to the act of moths playing with burning lamp at night; a clear indication of the danger they expose themselves to. He declares to a small group of refugees: "Hill fires are dangerous..." (p. 57). Fire has been used as a destructive factor in both The Silent Cry and Black Rain.

The atomic bombs dropped in parts of Japan in Black Rain and Takashi in The Silent Cry have been used to bring the same effect in their respective texts. The dropping of the atomic bomb by the enemy forces causes a lot of suffering to the people affected. This is both physical and psychological. The destruction caused by the Hiroshima bomb is beyond comprehension. Shigematsu says how a woman who owned Takahashi Spinning-Comb Works embraces him in fear and tells him: "Whatever can have happened, Mr Shizuma? Such horror!" (Ibuse, p. 45). Shigematsu's own immediate reaction is: "whatever it was- a bomb or whatever- they've gone too far. Yes it's too much!" (p. 46). The confusion caused by the attack is quite evident in Shigematsu and the woman. While Shigematsu loses his glasses without noticing it, the woman loses her bag and she too doesn't notice this immediately. It is only later that she laments "That bag had more than three thousand yen in it. My money and my savings book and my seal" (p. 48).

The atomic bomb from then henceforth, serves as a reminder of an ugly past. People appear to lose hope and live in fear constantly. It is this attack that in the end forces the state to surrender and accept defeat in the war. The atomic bomb becomes the most dreaded thing in the community, just like Takashi is dreaded in the valley in Silent Cry. Through his group of youth, Takashi spreads fear through all the residents of the valley - who fear to confront him (Oe, p.199).

The effects of the atomic bomb go beyond the destruction of human life and property. In Ibuse's Black Rain, Shigematsu reports on how it killed the fish, "Even though I knew that fish had skins more sensitive to sound than human beings, a nameless dread still filled me whenever I wondered what type of bomb the ball of fire had been, or what its scientific effects might be." The bomb also destroys a school leading to many deaths, a student from the Hiroshima Industrial College tells Shigematsu "more of the others were crushed to death. Some of them were caught underneath but got out injured" (p. 89).

The most devastating effect of the atomic bomb is, perhaps, the taking away of sexual urge in all it affects; hence killing all the future generations. Shigematsu overhears a rumour that "Tamotsu and Rikuo had been saying that those injured by the bomb, even if only slightly hurt had all lost interest in 
sex" (Ibuse, p. 211). Shizuma, whose only injury was a burn on the cheek, realizes that he had also lost all interest in sex. When the manager at Shigematsu's work place comes to visit him to bid Yasuko and Shigeko bye he tells him gloomily about the bomb: "It gives off a terrific radiation. I myself saw some bricks in the ruins that were all burnt away, with bubbles raised on the surface. The tiles, too, had gone a kind of flame colour. A terrible thing they've produced. They say nothing'll grow in Hiroshima or Nagasaki for another seventy-five years" (Ibuse, p. 282).

It is also after the atomic bombs were dropped that Japan finally concedes defeat. This is from a report given by His majesty where he claims that: "The enemy is using a new and savage bomb to kill and maim innocent victims and inflict incalculable damage. Moreover, should hostilities continue any further, the final result would be to bring about not only the annihilation of the Japanese race, but the destruction of the human civilization as a whole..." (Ibuse, p.300).

The atomic bomb has also the effect of inflicting fear among the people as seen from part of the capitulation speech given by the Japanese leader. The atomic bomb and Takashi are among the major funerary symbols used by the authors in Black Rain and The Silent Cry respectively.

The resultant effect of the continued attacks by the enemy forces, in Black Rain, is the creation of fear amongst the people. The case is the same in Oe's The Silent Cry where there is a fight or any other frightening happening. As people flee to safer areas Shigematsu reports that some oil drums were exploding. The intense fear within the people fleeing is shown in Shigematsu's words when he says that "As one man, the refugees on the tracks began to run, but almost at once reverted to their former leaden tread, the tread of men utterly exhausted both physically and mentally" (Ibuse, p. 56). To this he adds that "At each explosion, the refugees began to run" (p. 52). With time the people had come to associate oil drums' explosions with real danger and disaster. They have to save themselves from imminent threat that comes with every explosion. A children's play that Shigematsu is told about unfortunately ends tragically with the death of one of the actors. The tale causes Mitsusaburo a lot of agony for a long time. About his feeling when he saw that he says, "I was seized with fear, collapsed screaming on the floor, went into convulsions and lost consciousness. When I came to, I'd already been carried home and grandmother was at my bedside...." (Oe, p. 95). The play enacted by the children is a thing he remembers many more years after. It is a frightening experience.

Wars and fights normally lead to strained relationships amongst members of a society. As people flee from the enemy attacks they get into a lot of confusion and some get separated from their children. A man who loses a child shouts its name in vain (Ibuse, p.58). In The Silent Cry Mitsusaburo shows how war led to their father away from them into the war and how this led into his suffering and eventual death (Oe, p. 96). The death causes a further family breakdown when $\mathrm{S}$ believes that their mother refuses to divulge more details regarding their father's death. Thinking that the mother is mentally affected following this death, he sends her to hospital, this action causes irreparable damages to the family relationship.

While concluding her recollection diary on wartime diet, Shigeko makes this declaration in her writing: "I realized too, that war's a sadistic killer of human beings, young and old, men and women alike" (Ibuse, p. 71). She further describes how the city of Hiroshima loses its beauty because of war. Shigematsu, who is the narrator also, makes a comment on war: "I hated war! Who cared, after all, which side won? The only important thing was to end it all soon as possible: rather an unjust peace, than a 'just' war!" (p.161)

The war fought between Japan and other powers has direct impact on citizens, some of who are innocent and not directly involved in any conflict. People who are said to be survivors of the Kojin Unit and who are hosted in a borrowed room are said to be in a lot of suffering as a direct effect of the war. "Some of these were dying of raw burns, others groaning and excreting blood, and the same, foul odor hung over them all" (Ibuse, p.203). The odor from them is very strong and causes a lot of discomfort to people who inhale it. The raw burns would also cause discomfort to other people. The conflict between locals and Korean settlers, perpetuated by Takashi through his group of youth in the valley (The Silent Cry), has a lot of effects to people even if it takes the form of a cold war. The Korean supermarket owner faces open hostility from the valley people and they in turn have to pay more for goods, to cater for the lose they caused (Oe, p. 250-251). Further impact of war is seen through Hiroshi in Black Rain who feels that the doctor who treated his ear did not appreciate his gift 
of a bottle of sake. He blames war for producing people who are changed, like the doctor: "what is quite sure was that it never did anybody any good" (Ibuse, p.262).

Due to the ongoing war Shigematsu comments that at the time most of the essential things had become so scarce that one needed to have connections to have them, "commodities were so scarce that it was hopeless for anyone without such connections to get hold of food." It is because of this effect of the war that Shigeko and Yasuko decide to go to their country home in the hope that things would be better there (Ibuse, p.278). On his part, Shigematsu, after hearing about a woman who sends her son to be trained as a human torpedo, and as he stood before the woman's body after her death he wonders why she could not have prevented him from joining the training. Shigematsu in the end concludes that war "paralyzes people's power of judgment" (Ibuse, p.143). He thinks this is what happens to the woman, he is affected when thinking about this and the "sermon on mortality" comes out only as a faint whisper (Ibuse, p.143). Mrs Ariki who had a closer relationship with the dead woman is affected as seen in the way she thanks Shigematsu, "in a voice charged with emotion," (Ibuse, p.143). War is to blame for this.

In their movement to safety; Shigematsu, Shigeko and Yasuko come across disturbing things that have to do with death. Things like a dead woman whose hair is caked with blood, most of her body covered in blood and eyes and teeth left open and showing white (Masuji:96). As they pass each of these grotesque sights Yasuko is overcome with emotion as she stares at each and with each she keeps calling into her uncle to see, "Again and again, I had to tell her; 'It's not a show. Anyhow, there's nothing we can do for them, so keep quiet and come on. Keep your eyes on the ground" (Ibuse, p.96). The extent of death is seen in Shigematsu's description where he says that many were the times they stumbled on dead bodies or fell forward dipping their hands into hot asphalt (Ibuse, p.98). These images of death torment Yasuko for long; it is the same case with Mitsusaburo, in The Silent Cry, who is tormented by the thoughts of a friend who commits suicide throughout the text.

These descriptions serve the purpose of showing the rate at which people died and the risk involved. They also kill the spirit of the living as they see the people who have died and the conditions under which they died. No wonder that the people are overcome by sadness. The deaths described in the text are part of the funerary symbols. It is also from these bodies that Shigematsu believes his niece Yasuko, contracts the radiation disease.

Later on Shigematsu once again takes some time to describe the corpses he and Shigeko and Yasuko come across. The description given serves as a clear indication of the emotional suffering he and others went through. He says, "The bodies were completely naked and scorched black, and the buttocks of each rested in a great pool of feces. Nowhere else had I witnessed such a scene! The hair on their heads and elsewhere was burned away, and it was only by the contours of the breasts, for example- that I could distinguish man and woman. How had they come to meet such a grotesque death?" (Ibuse, p. 99)

Still on the same talk of death, the crematorium is reported to be jammed (Ibuse, p.130) and the burning of bodies has to be done anywhere (p.131). These are grave descriptions that fill the characters with fear and a state of hopelessness.

Miyaji's death is described as one of the most tragic and painful deaths in the text Black Rain, just as the death of Takashi is in The Silent Cry. This is because his death happens after he has lost his property to the flames of fire and gone through a lot of physical bodily pain as a result of the burns he suffers from the fires (Ibuse, p. 83). The death affects Shigematsu and through him the reader. The death of Takashi on the other hand happens at a time when he has established himself in the valley and his influence is felt by all through his group of youth.

Grotesque deaths, the narrator describes some of the deaths in a way that can cause fear to the readers and the characters themselves. A superintendent- General Otsuka dies in an extremely painful way. $\mathrm{He}$ is said to have burned to death. This happens to both the human and the animals. Just like the other death sceneries, these scenes serve only to fill the characters with fear and a state of hopelessness. They are funerary symbols.

In the context of the text the water tank that Shigematsu sees poses a threat to people's lives. Shigematsu sees three dead women in the water. He is overtaken by the sight and he just cannot keep his eyes off the bodies. The description of the corpses is also quite disturbing. From the buttocks of 
one of the dead bodies in the water tank is "A length of more than three feet of large intestines... it was swollen to about three inches in diameter..." (Ibuse, p.159).

In Nekoya-cho Reception Centre for corpses Shigematsu says he "could see a pile about six feet high of dead bodies." (Ibuse, p. 159) He keeps seeing the decomposing bodies with a cotton towel "but still the stench that came following after me was enough to make my head reel" (p.160). This was a disturbing scene.

In a similar manner, Oe's The Silent Cry has also shown various devastating images that have to do with war. After failing to make a phone call due to the worsening state of snow and communication breakdown, Mitsusaburo sees two mature men who are engaged in a fight. The fight is so grotesque because these are elderly men who fight openly before children and women and would not use their reasoning. In the fight one of the men dislodges the other's tooth and part of his gum. The narrator says that the incident fills women, children and Mitsusaburo himself with a lot of sadness. "I stretched out my hand, picked it up in my fingers, and then flung it down again, my guts gripped in a spasm of revulsion. It was a dislodged tooth and part of the gum... stole fearful glances at me...." (Oe, p.167). After witnessing this Mitsusaburo says that, "I was so disturbed...." (p. 168).

When explaining to Mitsusaburo, Takashi says that "The people who used to get rid of their pent-up aggression by watching or mediating in the kid's fights and quarrels are busy fighting each other this time," (Oe, p.168). The fact that nobody attempts to stop the fights dispels doom and hopelessness. Takashi interprets this as a sign of the valley turning into something worse- A ghetto (p.169). The policeman is also kept away by the falling snow. Just like in a ghetto, there is no security and Takashi is training the youth for himself.

Apart from the atomic bomb the enemy forces drop many more bombs, in Black Rain, which affect the people's livelihoods in various ways. They too are said to be very destructive though not on the same magnitude as the atomic bomb. Shigematsu says that "Kure was raided on June $22^{\text {nd }}$, then July $1^{\text {st }}$ a great incendiary raid razed the flat, central area of the city to the ground" (Ibuse, p.192). These ones are followed by the dropping of the atomic bomb on August $6^{\text {th }}$ in Hiroshima city.

Following the decision of the government to have black-out regulations in Ibuse's Black Rain, communication is drastically affected as people are not allowed to use lanterns to light the way at night. Due to this the head of the fire brigade in Kobatake village cannot be contacted when an important decision is to being taken by the headman in the village. The attack in the supermarket in Oe's The Silent Cry also disrupts people's lifestyle for a while as they have to buy commodities at a higher price. Jean's health also worsens in an effect that is directly related to the attack.

When the emperor reopens the supermarket, that had been closed following a breakdown by Takashi's youths and the villagers, he increases the prices of commodities by an average of $20 \%$ or $30 \%$ more than before the trouble (Oe, p.250). This was aimed at compensating for the losses incurred. After this riot and the subsequent closure of the supermarket, Jin "... ate almost nothing now and was rapidly growing thinner" (p. 251). The riot, hence, ends up having adverse effects on many people long after it occurred.

The smoke that engulfs Shigematsu, Shigeko and Yasuko in Black Rain as they move poses a real mortal challenge as it threatens to suffocate them. It can be described as a funerary symbol. Shigematsu says, "The wind gradually dropped, and the smoke ceased moving, which made breathing more and more difficult... once when we were brought to a halt, blinded by the smoke, the smoke and the heat pressed in on us, and breathing would have become unbearably difficult if the wind had not changed just at the moment. Yasuko gave a shrill, suffocated cry, and I had to shout at her ...." (Ibuse, p. 98). From the way Shigematsu describes the smoke it is no doubt that it posed a real threat to their lives.

When Yasuko develops the atomic disease Shigematsu cannot help recalling the days when they moved through the hot ashes of the burned city. He knows that this could have been possibly the cause of her infection and the place where she got the disease from. He therefore blames himself for the turn of events knowing quite clearly that he could have prevented that from happening, "Shigematsu felt very much to blame on this score" (Ibuse, p. 236).

The war makes it necessary to give people some military training to enable them defend themselves. This however does not augur well with some people in Black Rain, this is especially when it is the 
young who have to train the elderly. One of the characters in the text reports that in one of the trainings a man called Nakamura even contemplated committing suicide because he was kicked by some younger person than him, a trainer. The victim feels "like a father being bullied by his own son" (Ibuse, p. 241). The elderly people in the valley, in The Silent Cry, also get very uncomfortable when they see Takashi in an effort of trying to get the control of the entire valley for his own selfish gains.

The burns and injuries sustained by Hiroshi are so extensive that they cause the people who are close to him emotional suffering. While talking about his condition, he himself says that his injuries “...consisted almost entirely of burns, on my head, face, neck, wrists, fingers, and even lobes of my ears. The skin was peeling off my wrists; my back, they told me, was like a piece of raw beef, with the ribs all but poking through..." (Masuji:254). As a result of this he suffers a lot. His comments concerning the bomb are that it "had been a power beyond the mind of man to conceive." (Ibuse, p.254) It is therefore quite clear that this character has been totally incapacitated by forces beyond his control. This is the same case with Mitsusosaburo's son, The Silent Cry, who is born totally incapacitated and has to be taken to an institution because the parents cannot stand his condition (Oe, p.32).

Mitsusaburo, the narrator in Oe's The Silent Cry, blames what he refers to as 'chunk of stone' to his loss of sight in the right eye. He tells how at one time he had good sight and how one day as he walked along some street some children threw a stone at him, this stone cost him his right eye which in turn has caused many other undesirable things. He says that he has hurt himself on the right side of his face because of this. Because of the same he confesses that he looks uglier than he did before and that the same eye serves as reminder of this, something he would have wished to forget about. The stone has therefore caused the narrator many other 'misfortunes', it is a happening that was beyond him. He blames his lost eye for emphasizing the ugliness he had since his childhood. This is now a constant reminder since birth denied him joy "...it was the missing eye that continually dragged it out into the limelight." Hence, the lost eye continuously haunts Mitsusaburo as it reminds him of his ugliness.

The sad news that the entire population of pupils of the Hiroshima First Middle school had been wiped out in an enemy raid affects everybody who gets to hear of it. The children killed are quite many and innocent. On her part Hiroshi's wife says that when she got the devastating news "I felt as though my chest would burst- it was so cruel" (Ibuse, p. 266). This is a source of pain at the time it happens and the times to follow. A similar case is when the young men who are rearing chicken in the valley, The Silent Cry, lose all their chicken to a strange disease. They get so affected and vulnerable to Takashi's manipulation. Takashi takes advantage of their helplessness and hopelessness to use them in his uprising in the valley.

Takashi youth take after an uprising that had taken place earlier on in 1860. This uprising, that Takashi adores, is known for having done many wrong things. They caused havoc in the area; destroyed property and had sex with people's wives and daughters. "They mercilessly cut down people who got into disputes with them, and I'm sure there were some who, finding themselves none too popular with the women made do in the meantime with rape." (Oe, p.153) The youths and their uprising were therefore, very unpopular with the locals and the authorities of the day.

The live broadcast by Highness declaring Japanese acceptance of defeat cause people a lot of sadness, perhaps considering what would happen and does happen in war situations. Shigematsu says:

I walked along the corridor towards the canteen. A stream of workers passed me, their expressions grimmer than I had ever seen them before. Some of the male hands were crying. Some of the girls had covered their faces with work hats. One of a group of several factory girls making their way back to their dormitory had her arm around her companion's shoulder and was saying soothingly, 'Don't cry, dear! There won't be any more raids now, will there? (Ibuse, p.297)

The broadcast by the head of state in which he concedes defeat to enemy powers means that his country falls to the control of enemy powers. This is a hurting broadcast to people who love their country to see it under such a state. Tears are shed for Japan. Hence, though the broadcast means that there would be no more attacks on the people, it is still a funerary symbol because it does not portend well for Japan. 
In Oe's The Silent Cry, Takashi's uprising comes to an end with his death through a suicide. This is supposed to be a great relief because just like in Black Rain it means that people will not only live but they will live in peace. This, however, cannot be the case because the people of the valley will have to pay for their youth's misdeeds as the prices at the supermarket are hiked. The family is also greatly affected as they lose yet another family member, a member who takes his own life after selling family property.

Although situations of instability in both texts seem to improve with the ending of the world war and the death of Takashi, in Ibuse's Black Rain and Oe's The Silent Cry respectively, there is fear of returning to the earlier state. A young priest laments that if the attack on the supermarket were to spread then farmers would attack supermarkets all over and "If that happens, the flaws in the economy will show up immediately" (Oe, p. 199). Such acts would affect the economy greatly. Shigematsu on the other hand, in Black Rain, still gets a feeling that the world was still in danger of the above (Ibuse: 204). This shows that the fear resulting from what had happened during the war was still there. In the war an atomic bomb had been dropped on Hiroshima on August 6, 1945 (May, 2003, p ).

\section{SUPERSTITIONS}

In a train that Shigematsu and other people who are affected by the bomb are traveling, and in the midst of suffering and mourning in the train where one of the women passengers is carrying a dead child, "a kite was wheeling in the air above the wires." (Ibuse, p.114) The usage of a kite at a time when we are told that there is pain to most of the passengers who are affected by the war and to the woman passenger who is carrying a dead child seems to be used to announce or show mourning. Hence the wheeling of the kite is deliberate; it is a funerary symbol within the context of the text.

Most of the victims of the atomic disease are faced with the problem of their hair falling off from their bodies as the disease progresses. With time this has become a way of identifying the victims who would not survive the disease. This is as claimed by some people from whom Hiroshi's wife learns it. Hiroshi's wife therefore gets worried when her husband's hair begins to fall out easily (Ibuse, p. 264). Though he survives the disease, this becomes a funerary symbol because such a thing would be enough to set the people who are close to an affected victim into panic and despair. Yasuko's disease has also developed to a point where her hair falls out easily and her teeth become very lose.

Sermon of mortality, this is the sermon that Shigematsu was required to say for the dead before they are taken to the crematorium to be cremated. He, however, due to the sceneries he has had and out of the effect of hopelessness murmurs it to himself before crossing a river in his movements. He then says that he does this "sooner or later, on this day or the morrow, to me or to my neighbor...so shall the rosy cheeks of morning yield to the skull of eventide. One breath from the wind of change, and the bright eyes shall be closed..." (Ibuse, p. 277). The sermon of mortality is a funerary symbol in religion because it would not and it was not supposed to be said if there was no death. When said to the living who are expected to die it then shows the state of hopelessness.

Dreams in the Japanese society portend different issues and can be interpreted differently depending with the nature of the dream. Shigematsu's sleep is disturbed by a dream in which he sees a onelegged man in a kimono hopping after him with a long spoon over his shoulder. He wakes up sweating because of the dream (Ibuse, p. 286).

White rainbow crossing the sun horizontally is given a symbolic meaning in the context of Ibuse's Black Rain. Shigematsu sees this and when he tells the others about it the manager who had also seen one at an earlier time declares, "It's an omen... a white rainbow bodes nobody any good." Another person at a government office concludes on what Shigematsu sees by saying "white rainbow that pierces the sun' - it was a sign from heaven that armed disturbance was imminent..." (Ibuse, p. 293). What follows after the rainbow is that Japan concedes defeat in the war. With this conceding it is highly expected that the Japanese armed forces will be disarmed and that Japan is to be occupied by foreign forces.

The dead body of the brother of the narrator and Takashi, S', is regarded as representing misfortunes and that is the reason as to why many of the family members and neighbours are said to be scared of having anything to do with it. About it Mitsusaburo says, "It was dusk by the time I got him back to the valley, but none of the adults came out of the houses lining both sides of the road. Even the 
children only peeped out, and hardly showed themselves. They were scared of having anything to do with the corpse and the misfortune it represented" (Ibuse, p.72).

Mitsusaburo says how his mother used to fear sharp objects. He dreams seeing her injuring herself deliberately and rejoicing afterwards because she believes that it would lead her being excused from some taxing labour (Oe, p. 103). Mitsusaburo says, "Every morning I accompanied mother - who just as in my dream was afraid of axes and all sharp instruments...."

Nembutsu music played out of season, Mitsusaburo complains over Takashi's idea of playing this music out of season in order to spread his influence on the people (Oe, p. 184). "The Nembutsu music nagged at me unceasingly, torturing my nerves, sapping my mental energy" (p. 185). It is, therefore, true that he plays the music for selfish and wrong reasons. Some of the people like Mitsusaburo are not pleased by this at all. The fact that Takashi uses the music to spread his unpopular agenda in the valley makes the music, as played out of season, a funerary symbol.

A gun spells danger. This reality is brought out in the text when Takashi in the end fires from his gun (Oe, p.243) and Mitsusaburo, Gii and Jin's children are shaken. Even Momoko and Hoshio, who are asleep, turn in their sleep. This is an indication of the danger posed by a gun and by extension the confirmation of the same as a funerary symbol. In the end Takashi shoots himself in the storehouse (p. 243-244).

Chosokabe is an imaginary creature that was believed, by the narrator's mother in Oe's The Silent Cry and other people, to be very terrifying because of its physical size and ability to be found everywhere in time and space (p. 42). People believe that this creature is indeed there and that it had the ability to harm them physically. The narrator also says that the mother would use chosokabe stories to scare them whenever the narrator appeared to question her authority.

In some of the Asian communities, including the Japanese, whistling after dark is a highly discouraged thing. In Korean superstitions (seoulistic.com) whistling after sunset was prohibited because it was believed to attract ghosts and snakes into homesteads. In The Silent Cry, through Takashi and Mitsusaburo we get to learn that whistling after it is dark was a highly discouraged thing and as Takashi tells Natsumi the valley folk would get very annoyed. This is because in the village there is a belief that whistling at night would attract a supernatural being from the forest. The narrator says, "...They believe that if you whistle after dark a supernatural creature will come out of the forest. Grandmother used to tell us the Chosokabe would come." (p.59)

Jin's dreams have a devastating effect on her as they completely deny her peace. When she meets Mitsusaburo, Jin complains of not having a peaceful night, "Nothing but wretched dreams, dreams of being left without a house!" (Oe, p.62). She gets the nightmares because she learns that there were plans to sell off the family property including her own residence.

Paintings of hell are drawn on the walls of the temple in Oe's The Silent Cry. The paintings are meant at trying to reflect and show how the spiritual world is and the hell itself. They are therefore funerary symbols and are meant to be so by the author and the community. Unfortunately they scare many people, especially children. The priest says, "Taka always used to be scared of the hell picture, even when he was a kid" (p.69). The pictures are hence scary to many. They are funerary symbols because of their intended purpose and even what they do besides that.

Mitsusaburo's friend's writings, though the friend's grandmother had made a promise to pass these writings over to him after the friend's death, the relatives object and burn the writings. Mitsusaburo says that "They'd been afraid- afraid that another monster with crimson-painted head and a cucumber up its rear might leap naked out of the manuscripts and notes he'd left and threaten the world of those who had survived" (p.107). It is for the fear and the fact that the writings were thought to have a life of their own, and could influence one, that they were burned.

The unnamed forest spirits are to blame, according to Mitsusaburo, for some misfortunes that befall the people. These misfortunes include persistent floods that ravaged the valley and virulent rice pest (p.124). This is in accordance with the superstitions.

According to Mitsusaburo's mother this was a thing believed. Mitsusaburo's mother stands on the threshold and the after effect is that the father does not return, he dies on the journey (p. 218). 
Mitsusaburo gets to believe the superstition since his father dies after Mitsusaburo's mother acted in defiance of the superstition and taboo.

Darkness is used in the text, Oe's The Silent Cry, to represent evil and hence as a funerary symbol. This is clear from the things that happen in the cover of darkness. From the storeroom Mitsusaburo witnesses very many activities that happen in the night. Takashi claims to have murdered the girl he had attempted to rape during the night. His own death also happens during the night. Darkness, besides being a natural symbol of doom and evil is also used in the text as a funerary symbol in a special way.

\section{EFFECTS OF WAR AS FUNERARY SYMBOLS}

Radiation sickness is one of the infections that come with the dropping of atomic bomb in the cities of Hiroshima and Nagasaki. Following these attacks the victims develop a strange disease and their bodies weaken greatly, something that in the end results to death as the disease has no cure. The narrator reports about one Asajiro who is a victim, "His symptoms were the same. If he pulled a heavy cart or worked in the fields, he got an ominous rash of small pimples among the hair on his scalp...." This meant that even those with minor infections could not do manual labour. As Shigematsu argues, that "But people like us have only to do a bit of hand work and their limbs start to rot on them. The damned disease comes out" (Ibuse, p. 28). The suffering of the victims of the atomic disease is also described to be almost unbearable. The sick are further subjected to social rejection as seen through the woman from Ikemoto who subjects Shigematsu and Shokichi to sarcasm alluding that they are lazy. The victims are further isolated physically upon developing the symptoms of the disease.

The disease is very much feared by the people because of its contagious nature and lack of cure that whoever is said to get it faces isolation and open discrimination from their society. When the family of the young man who wanted to marry Yasuko learns from her that she is sick from the radiation disease and she already shows symptoms of the disease they cut all communications and break this engagement. She is also isolated physically as she is put in a room of her own. Besides the open discrimination faced by the victims of the disease, affected people like Shigematsu also suffer unspeakable pain. Because of this, the disease becomes something to be feared by all. It is a funerary symbol because it deprives its victims the acceptance they need, causes them pain and hopelessness as it has no cure. May (2003) while showing the gravity of the sickness says, “... radiation sickness is a bad way to die and indeed not a particularly wonderful way to live."

When Shigematsu's family receives a letter enquiring on the health of Yasuko, she and Shigeko weep. When Shigematsu finds them sobbing he is deeply saddened by the spectacle and admits that he had written an assuring letter on the condition of Yasuko. It is this that could have triggered the sending of the letter they were now reading. All of them know from within that the letter could not portend anything good for the intended marriage between Yasuko and a young man from the Aonos family.

The city of Hiroshima also becomes a source of painful reminder of the killings, pain and destruction that come out of the bomb attack that is dropped in the city by enemy forces during the war. From the attack there are fires, people contract a new disease and get displaced and destitute in the same city or in other cities as well. Because of the destruction meted upon the city Shigematsu is said to shed tears (Ibuse, p.18). The atomic bomb was dropped on Hiroshima on August $6^{\text {th }}, 1945$.

The reader gets to know that the black rain that fell after the atomic bomb is associated with sad things when Shigeko objects to sending the part about it from Yasuko's diary. This is when copying her diary to send to the family of her intended suitor. She sees it as something that will bring a bad impression. It is hence clear that black rain has assumed a symbolic meaning and when used with reference to anybody it would impact negatively on the person referred to. Shigeko tells her husband "But nowadays everybody knows. If we leave that part in when we send them a copy, mightn't they get the idea?"

Anybody who is rained on by the black rain gets spots that won't get off. Yasuko is one such a person and regarding this she writes in her diary, "I washed my hands at the ornamental spring, but even rubbing at the marks with soap wouldn't get them off. They were stuck fast on the skin." (Ibuse, p. 35) 
The rain falls after the dropping of the bomb and cause a lot of discomfort and confusion because from it people get marks on their bodies, marks that won't just be washed off. It is said in the text that "They say it's the black smoke generated by the explosion. It mingled with water vapour in the sky and got carried down in the rain. The black rain fell mostly in the western districts of the city." (Ibuse, p.93)

Mrs. Miyaji's comments on the alteration in the text books leads to her being summoned by the authorities where she is given a warning for saying that there were changes in her child's book about the ration of rice given. Due to the biting effects of the war going on the authorities are forced to reduce on the ration of food given to people because of the scarcity of the same. They therefore adjust the information in the children's books. Mrs. Miyaji, however, notes this and speaks about it. It is because such talk could break people's will to keep on fighting that the authorities summon her and give her the warning, "Irresponsible talk in wartime is a matter that's too serious for the ordinary civil or criminal code" (Ibuse, p. 66).

Following the dropping of the atomic bomb some of the victims get indelible marks in their bodies. One of these is Yasuko who gets these marks in her hands. Shigematsu tries to help his niece get rid of them but all his efforts are in vain. The marks cause the victims and their relatives a lot of discomfort "...but the marks would not come off. She said they were made by the black rain and they were firmly stuck on the skin. They were not tar, nor black paint, but something of unknown origin" (Ibuse, p.92). The marks remain a painful reminder of the tough past that the characters have been through.

One of the victims of the atomic disease is described to be in great pain as he throws himself about in agony and spews up yellow liquid before he succumbs to his disease. This yellow liquid has been used by Ibuse as a funerary symbol that signifies extreme suffering.

Ibuse has described the crematorium in a way that creates a disturbing picture in the mind of the reader, at the time of endless deaths. Mutsuki (2008), describes a crematorium as a gateway to the next world and hence both sacred and dangerous. Mitsusaburo gives a detailed description of the crematorium and how it looks with the remains of the burnings of the corpses "I could see bones in most of them, and the skulls especially stood out with strange clarity... some of the skulls gazed fixedly at the sky with empty eye- sockets, others clenched their teeth in angry resentment" (Ibuse, 138). The effect of this sight on Mitsusaburo himself is evident in the way he reacts. He is so shaken that that he murmurs "sermon on mortality" to himself. This scene remains in his mind for long that he says afterwards that "...in my mind's eye, like a waking dream, I could still see the tongues of fire at work on the bodies of men" (Masuji:139). He realizes much later that due to the effect this had in his mind he had actually drenched himself.

A janitor reports that there was smoke from all parts of the dried up parts of the river bed. "The crematorium was jammed, and there was no time for people to wait their turn," (Masuji:130). The deaths were too many that "Haste then, was the order of the day. They must be burnt on the river bed, in the hills- anywhere away from human habitation.

Shigematsu also gives a detailed description of the cremation process and skulls which he describes as "the unsheltered ones" (Ibuse, p.138). And as he moves away from the scene he describes that he was "murmuring the "sermon of mortality to myself".

According to John (2012), cremation is normally done in the absence of the relatives and after the process the relatives arrive and pick the ashes and the bones. No bone is left behind. When Shigematsu, therefore, sees so many bones which include skulls he is bound to be disturbed. This scene and the people burning the dead by river beds, serve as a clear sign of the extent of loss on the people affected. This is why Shigematsu utters the sermon to himself, because he cannot see how he will be alive for long.

Mosquitoes are a threat to the health of people and hence they are normally kept away as far as possible. This is still the case in the text, one of the characters, Mr Nakao, tells Shigematsu that the bomb raid brought with it "... a sudden spate of striped mosquitoes" (Ibuse, p.174). People are forced to protect themselves from these insects because they pose a challenge to their wellbeing.

People who are affected by the bomb are said to smell a lot and Shigematsu reports that they could be identified easily because of the most awful smell they produced. This smell causes a lot of discomfort 
to other people and can rightly be termed as a funerary symbol because the smell emanates from war and is directly related to the war and the atomic bomb. Apart from being a painful reminder of what is happening the smell causes other people a lot of discomfort. Shigematsu says that it was "a most offensive smell...the smell of the victims of the bomb" (Ibuse, p.211). He tells a lady who smells that "you stink to high heaven" (p. 212)

Shigematsu says the following concerning a driver of a vehicle they travel in with the wife Shigeko "...we drove to Fuchu sitting by the driver, who had a pad over his mouth and nose to keep out the smell that the bomb victims gave off" (Ibuse, p. 262).

A lady given number 47, Tamiyo Oshim, decides to work tirelessly for the welfare of the victims of the war, the husband having been taken prisoner of war in Siberia. This fills her with sad memories and it is due to this that she dedicates herself to what she does for the memory of the husband.

Dr Kajita's father's stroke, this is the doctor who treats Yasuko when she develops the atomic disease. He keeps coming to make regular checks on her as he treats her. His father however gets a stroke and the doctor has to travel to go and attend to his ailing father. This is bad news because it means that Yasuko would not be attended to by a doctor she is used to. The doctor he also recommends, Dr Moriya, is not in very good terms with him. This is as recorded by Shigematsu (Ibuse, p.227).

Yasuko suffers several abscesses which continuously deny her joy and cause her a lot of pain especially at night (Ibuse, p. 229) in Kuishiki Hospital where she is admitted, her fever is blamed on these abscesses. It is reported that at night she kneels and sobs because the pain from the abscesses is unbearable (p. 232) we are also told that "New ones are forming and old ones breaking all the time" (p. 233). Eventually the places where the abscesses are excised "... would not heal. The flesh remained red and puffed up like a split water melon" (Ibuse, p. 235). They cause the sick a lot of pain and can therefore be said to be used on purpose by the author as funerary symbols.

Following the continuing war and the ever rising cases of attacks from the enemy forces, the number of the sick is reported to be rising all the time. In one of the reception centres, for instance, where Iwatake is taken the place is said to be over flooded by the sick that some of them have to be moved to an army branch hospital at Shobara because of the lack of space. Iwatake who has sustained burns from a fire is one of the people who volunteer to be moved (Ibuse, 249). The rising number of the sick strains the medical services and creates a sense of hopelessness.

Patients groaning at the hospital, when Hiroshi's wife goes to the hospital where her husband had been moved she gives a grave report of people in extreme pain, pain which also appeared to be collective. It is surprising to see that she notes that "One thing that struck me as strange was that when one patient groaned all the others would start groaning at the same time. It was an uncaring soundperhaps I should say it, but it was for all the world like a chorus of frogs starting up in a paddy field" (Ibuse, p. 259). This was a clear indication of pain and suffering that was incomprehensible and beyond explanation. The groaning was therefore a funerary symbol on the actual feeling. Iwatake's face is also said to have swelled to twice its normal size.

In his sickness Hiroshi suffers a lot of pain from an earache in his right ear. This pain is only stopped when an arrogant draft lieutenant called Kutsubara attends to him and the above oily liquid mixed with maggots is removed from his ear. This experience caused him discomfort and suffering.

Iwatake, one of the people who get seriously affected by the atomic disease but survive it, is left with one problem which serves a painful reminder to him of the dangerous days of pain when the atomic bomb was dropped by the enemy forces. He writes "The thing that troubles me is the ringing; it persists in my ear day and night, like the tolling of a distant temple bell, warning man of the folly of the bomb..." (Ibuse, p. 270). The ringing which is a problem that would not heal after his ear had been infected is a funerary symbol that keeps his mind in constant memory of the sad past.

A bamboo grove in the valley is said to be the greatest and the most realistic reminder of the painful days of the 1860 when there was war. The narrator says this about bamboo grove "was the most incontrovertible reminder of the 1860 rising, whose memory, during the war, had been viewed as a slur on all the inhabitants of the valley." The narrator tells how the area headman and others had been "...ashamed that their ancestors should have cut bamboo for use in a rebellion against the establishment of the day...." (Oe, p.104). 


\section{CONCLuSion}

In this paper we identified and expounded on the funerary symbols used in Ibuse's Black Rain and Oe's The Silent Cry. The authors have used a wide range of funerary symbols to present their story. Some of the characters in both books have been used as funerary symbols. The writers have also used natural factors, superstitions and other creatures as funerary symbols to create an appropriate mood, attitude and atmosphere for their stories. It has been noted in this chapter that most of the symbols used in the two texts are similar. There are, however, some of the symbols that are unique in one text and not reflected in the other text under study.

\section{REFERENCES}

[1] Abe, K. (1993). Three plays. New York: Columbia University Press.

[2] Alot, M. (1982). People and Communication in Kenya. Nairobi: Kenya Literature Bureau.

[3] Barthes, R. (1967). Death of the Author.New York: Noonday Press.

[4] Barthes, R. (1988). Mythologies. New York: Noonday Press.

[5] Bochat, W. M. (2008). Atomic Bomb: Memory and its Power on Japanese Pacifism. Tokyo: Bochat W.M.

[6] Brueuggemann, B. J.(1958). Deaf Subjects: Between Identities and Places. New York: new York University Press.

[7] Cameron, L. (1998).The Music of The Light: The Extraordinary Story of Hikari and Kenzaburo Oe. New York, NY: Free Press, 1998.

[8] Cameron, L. (2013). The Virginia Quarterly Review; A National Journal of Literature and Discussion. New York, NY: University of Virginia.

[9] Chandler, D. (2005).. Semiotics for Beginners. Wales: Aberystwyth University, 2005.

[10] Chatman, S. (1971).. Literary Style. London: Oxford University Press.

[11] Chirambo, R.M \& Makokha, J.K.S. (2013). Reading Contemporary African Literature: Critical Perspectives. Amsterdam: New York, NY, 2013.

[12] Dewey, J. (1988). Nuclear Holocausts: Atomic War in Fiction, 1895-1984 (review). Baltimore: The John Hopkins University Press.

[13] Dickson, E. ( ）. The Emily Dickson's Journal: Emily Dickson's vision of "Circumference" and Death from a Japanese Perspective. Tokyo: The John Hopkins University Press.

[14] Educational Outreach Department (2012). Japanese Literature for the High School Classrooom. New York, NY: The Freeman Foundation.

[15] Freud S (1966). The Psychoanalysis of Everyday Life. London: Hogarth Press.

[16] Freud S. (1973). The Standard Edition of the Complete Psychological works of Sigmund

[17] Freud; volume XVI. London: The Hogarth Press.

[18] Freud, S. (1994) The Interpretation of Dreams. London: Random House Publishing inc.

[19] Freud S (2000). The Psychology of Everyday life. London: Hodder and Stoughton Publisher, .

[20] Gage, R. L. (1995) (ed. Trans). A Dialogue between John Galtung and Daisaku Ikeda. London: Pluto Press.

[21] Gage, R. L ( ) (ed. Trans). A Lifelong Quest for peace, A Dialogue by Linus Pauling and Daisaku Ikeda. Toronto: Jones and Bartlett Publishers. Print.

[22] Humphries, J (1997). Japan in Theory. Virginia: The University of Virginia.

[23] Ibuse, M (1970). Black Rain, trans. John Bester. Tokyo: Kodansha International.

[24] Ikeda, D. (1988). Unlocking the mysteries of Birth and Death: Budhism in the Contemporary World. London: Macdonald and Company Publishers limited.

[25] Iser, W. (1980) The Reading Process; Phenomenological Approach. Reader Response Criticism; From Formalism to Post Structuralism. Baltimore: The John Hopkins University Press.

[26] Jameson, F. (2005) et al. Archaeologies of the future: The Desire Called Utopia and Other Science Fictions. New York: Verso..

[27] Jo, B. (958) et al. Coming-Out Pedagogy: Risking Identity in Language and Literature Classrooms. Durham NC: Duke University Press.

[28] Kimura, R. (1991). Japan's Dilemma with the Definition of Death. Tokyo: The John Hopkins University Press.

[29] Leech, G. \& Short M. (1981). Style in Fiction- A Linguistic introduction to English Fictional Prose. London: Longman Group. 
[30] Makokha, J.K.S, Obiero J. O. \& West-Pavlov, R. (2012). Style in African Literature. Amsterdam: New York, NY.

[31] Marcus, M. (1989). The Rhetoric of Confession: Shish A. Setsu in Early Twentieth- Century Japanese Fiction, and: Pools of Water, Pillars of Fire: The Literature of Ibuse Masuji (review). Baltimore: The John Hopkins University Press.

[32] Matthew, P. (2008). Holocaust and Genocide Studies; Far From Oblivion: The Nanking Massacre in Japanese Historical Writing for Children and Young Adults. London: Oxford University Press..

[33] McNeill (1999). Roland Barthes: Mythologies (1957). Sunderland: The University of Sunderland.

[34] Meurrell, F (1996). Semiotics and Literary Studies. Toronto: University of Toronto Press.

[35] Mishima Y. (1970). The Decay of the Angel. New York: Penguin Books Ltd.

[36] Mishima, Y. (1986). Death in Midsummer and Other stories. New York: Penguin Books Ltd.

[37] Oe, K. (1967). The Silent Cry. Tokyo: Kodansha Limited.

[38] Olson, E. (1965). Aristotle's Poetics and English Literature: A Collection of Essays. University of Chicago Press.

[39] Ong'ang'a, A. (2008). A Psychoanalytic Analysis of J.M. Coetzee's Characters in Elizabeth Costello and Slow Man. Unpublished M.A Thesis Kenyatta University, 2008.

[40] Rasmussen, D. M. (1971). The Hague: Mythic-symbolic language and philosophical anthropology, A Constructive interpretation of the Thought of Paul Ricoeur. Martinus Nijhoff.

[41] Rathus, A.(1994). Essentials in Psychology. (Fourth Edition) Harcourt Brace: Harcourt Brace College Publishers.

[42] Rosenberg, S. \& Robin, S. (2004). Psychology. The Brian, the Person, the World (Second Edition). U.S.A.: Pearson edition, Inc.

[43] Soseki, N.(1957). Kokoro. Washington: Regney Publishing..

[44] Surdulescu, R. (2002). Form, Structure, and Structurality in Critical Theory. The Semiotic Analysis of the Literary Text. Bucharest: University of Bucharest.

[45] Thomas, F. (1970). The Symbolic Language of Religion; An Introductory Study. London: SCM Press Ltd.

[46] Tyson, L.(1950). Critical Theory Today. Taylor and Francis Group Limited.

[47] Warren, A \& Welleck R (1942). Theory of Literature. Brian: Jonathan Cap.

[48] Wender, M. L. (2007). The Journal of Japanese Studies, Volume 33, The Body in postwar Japanese Fiction (review). Tokyo: Society for Japanese Studies.

[49] Wright, E. (1984). Psychoanalytic Criticism: Theory in Practice. Massachusetts: Methuen Publishing Ltd.

[50] Zimbando, P. (1980). Essential in Psychology and Life. (10 ${ }^{\text {th }}$ edition). U.S.A: Scott, Foreman and Company.

[51] Oe, K. (1998). Seventeen and J. London: Foxrock Media Limited .

[52] Editorial. "Disabled still face discrimination.” Japan Times: n. page 7 Oct. 2012. Web 2 Jan. 2015. Electronic.

[53] Lichtenstein, K., \& Helfand, I.(1994). Radiation and health: Nuclear weapons and nuclear power In Critical Condition: Human Health and the Environment, ed. E. Chivian et al. Cambridge: The Mit Press, 1994.

[54] Kushner, E. (2000). The Diagnosis: Japan Through the Eyes of Kenzaburo Oe. Eve Kushner.

[55] Francisco, A. (2014).Suicide in Japan: Five things to know about suicide in Japan. Retrieved from www. tofugu.com.

[56] Abe, K. (2015). Japanese and Chinese Literature: The Woman in the Dunes. Retrieved 24 th February 2015 from www.booksyo.wordpress.com.

[57] Wiren, A (20140. Japanese Funerals: Sunset in the Rising Sun. retrieved $22^{\text {nd }}$ September 2014 from www.japanvisitor.com.

[58] Mockett, M.M (2008). Letter from a Japanese Crematorium. Retrieved 21 st September 2014 from www.bu.edu.

[59] John (2012). Japanese funeral services: What happens when you die in Japan?." Retrieved on $20^{\text {th }}$ September 2014 from www.tofugu.com

[60] Forest B. (2014). The Significance and Meaning of Owls in Japanese Culture". Retrieved on $22^{\text {nd }}$ September 2014 from www.hubpages.com.

[61] Kitchen, L. (2014). Owls in Japan-Symbolism and Myth. Retrieved on $22^{\text {nd }}$ September 2014 from www.mrslinskitchen.com. 
[62] Semiotics. Retrieved on $20^{\text {th }}$ August 2014 from www.about.com. .

[63] Emanuel, P. (2014) Semiotics .www.academia.edu.

[64] Frellesvig, B. (2014). Old Japanese: Early writing in Japan and Old Japanese Sources. Retrieved on $25^{\text {th }}$ Feburuary 2014 from www.conf.ling.cornell.edu.

[65] Gilbert, H. (2014). Nawal El Saadawi - Woman at Point Zero. www.bbcworldservice.com/worldbookclub. Wbc_20090430-1632c. Web. 10 Dec. Audio.

Citation: James Nderitu, et.al. Funerary Symbols in Oe Kenzaburo's the Silent Cry (1967) and Masuji Ibuse's Black Rain (1970). "International Journal on Studies in English Language and Literature (IJSELL), vol 7, no. 12, 2019, pp. 25-42 doi: http://dx.doi.org/10.20431/2347-3134.0712002.

Copyright: () 2019 Authors. This is an open-access article distributed under the terms of the Creative Commons Attribution License, which permits unrestricted use, distribution, and reproduction in any medium, provided the original author and source are credited. 